\title{
Original
}

\section{Innovative societies in the fields of mental health and ageing: The French case}

\author{
Vincent Rialle $\mathrm{PhD}^{\mathrm{a}, *}$
}

aUniversity Grenoble Alpes, Lab. EA n ${ }^{\circ} 7407$ AGEIS (Équipe d'Accueil 'Autonomie, Gérontologie,
E-santé, Imagerie \& Société'), Grenoble, France; *Corresponding author: vincent.rialle@gmail.com

V. Rialle. Innovative societies in the fields of mental health and ageing: The French case. Gerontechnology 2020;19(1):4-15; https://doi.org/10.4017/gt.2020.19.1.002.00 Background The study is located at the confluence of healthcare, aging, and technology, and the pressing need for societal transformation. Research aim We present a reflective study aimed at analyzing the societal resilience against two health and social issues that have severely worsened in France: The gerontology sector has been shaken by the increase of degradation of quality of life in certain nursing homes, while the psychiatric institution has been stressed by the increase of homelessness and its own mental health issues. Against such backdrops, the societal resilience has produced a wealth of laws, ideas, and initiatives, including g cutting edge technologies, to enhance the transition towards a inclusive, sustainable and healthy (and so an innovative) society. Method Seven recent papers of the author, published from 2016 through 2019 in peer-reviewed French-speaking journals, along with some abstracts published in the Gerontechnology journal, have been gathered to furnish the basic materials of the reflective study. This set of papers deals with the above-mentioned psychiatric and gerontological social issues, along with a series of prominent innovations to tackle these issues by means of science, technology, and health policy. The study is focused on the French case in accordance with the 'case study' methodology and is devoid of any nationalism. Results The reflective study resulted in a threefold aspect of the societal resilience process: First, the awareness maturation step: From acute societal issues to innovation; Second, the public policy step; i.e., the French world of laws, action plans, and national ethical lighting to pave the way to solutions; Third, the social innovation and disruptive thinking step to achieve sustainable solutions. Conclusion Besides the important case analysis results, the research intends to be an incentive with some methodological hints to tackle the ISG's investigation area of gerontechnology and sustainable humanity.

Keywords: Sustainability, resilience, innovation, psychiatry, gerontechnology

\section{INTRODUCTION}

The purpose of the article is a reflective study located at the confluence of healthcare, social issues, aging, and technology, with a special focus on psychic health care. It aims at explaining and analyzing the societal resilience against two precise health and social issues that have severely worsened in France in recent years. Societal resilience is intended, in this paper, as the ability, from the combined action of civil-society bodies, to adapt and produce new ways of thinking and acting in the face of adverse conditions, hence transforming these conditions into opportunities and goodnesses. These health and social issues are amenable to the areas of (a) psychiatry and psychic health care, and (b) the tightly coupled fields of gerontology and geriatrics: The gerontology sector has been shaken by the increase of maltreatment, and the degradation of quality of life in certain nursing homes, while the psychiatric and psychic health care sector has been severely stressed by the increase of homelessness, and its cortege of mental health and addictions disorders. Both issues have evidenced the maladjustment of the French health system to face their magnitude and urgency.

Against such backdrops, the addressed societal resilience has produced a wealth of laws, ideas, and initiatives, including consideration of cutting edge technologies, to enhance the transition towards a knowledgeable, inclusive, sustainable and healthy society. The Reflective method that has guided the present paper rests on a series of recent studies and reflections published or CO-authored by the author. Though the true perspective of the paper is a demonstration of positive and stimulating aspects amenable to innovative societies, it is nonetheless grounded in somehow terrifying reality. Thus, it can be seen as a contribution to the famous Hölderlin's verse: "But where the danger is, also grows the saving power". However, the aspiration of the paper goes beyond the sole French case. Rather, it is to show, through 
this case example, the possible interest - for each country or region of the world - of such an approach, and to propose structured steps to carry out such a study of a reflective type. The whole research is in line with such a sound and ambitious theme as "gerontechnology and sustainable humanity" (Franco \& van Bronswijk, 2016) of the International Society for Gerontechnology (ISG). It may be considered as a contribution to extending the scope of gerontechnology towards issues regarding tomorrow's regions, megapolis, smart cities or green cities in the world.

After the present introduction, section 2 develops the methodology that has been used to fulfill the purpose; section 3 presents the results in four sub-sections: first, a short global overview regarding the structuration of the results; then, 3 sub-sections devoted to a thorough presentations of each of the successive steps that compose the societal resilience process; the last section provides a short discussion and conclusion.

\section{Method}

The comprehensive analysis and reflection about the complexity (Morin, 2008) of the path from acute health disorders and social problems to societal problem solving have been achieved by using a reflective study approach (Dewey, 1998; Moallem, 1998). We coined the expression 'societal resilience' to characterize this path; such an expression echoes the 'social resilience' concept which addresses the transformability of society in the face of global change (Keck \& Sakdapolrak, 2013).

Starting materials of the analysis were drawn on seven recent articles published in French-speaking journals from 2016 through 2018. What led to the choice of these articles may be specified as follows. Inclusion: paper published, or co-authored, by the author; paper related to the abovementioned psychiatric or gerontological social issues, and the ways to tackle these issues by means of science, technology, and health and social policies. Exclusion: paper not peer-reviewed.

The selected papers respectively deal more specifically with ethical Issues of Aging (Rialle, 2019), rethinking the organization of psychiatric care in the age of the Internet of Things (Sol \& Rialle, 2018), technologies and health of the elderly (Rialle, 2018b), humanitarian robotics (Rialle, 2018a), Collaborative life (Rialle, 2017a), smart cities sources of inspiration (Rialle, 2017b), and technology and total innovation (Rialle, 2016). Besides, the following eighth paper (conference abstract) in English was partially used: "How to think globally and act locally for health path, and elders' autonomy with eHealth and Gerontechnology?" (Rialle et al., 2016).
In addition, the study focuses on the French case with regard to a 'case study' methodology and is devoid of any nationalism. On the contrary, it aims to evidence a methodological path to a true innovative society that could be useful anywhere in the world.

\section{Results \\ Overview of results: A threefold structure}

The reflective study resulted in a threefold developing aspect of the observed societal resilience process (all websites indicated in the following are in French or refer to French speaking papers). (1) The awareness maturation step: From acute societal issues to innovation;

(2) The public policy step; i.e., the French world of laws, action plans, and national ethical lighting to pave the way to solutions;

(3) The social Innovation and disruptive thinking step to achieve sustainable solutions.

Beside this threefold aspects, the study illustrates the intercurrence and synergistic effects of two other processes that build the whole societal resilience: on the one hand, the popular creative push of innovative actions conducted by pioneers in favor of new ways of thinking and acting, intervening not against but at the frontiers of the democratic arena; on the other hand, the state's role devoted to relaying these pioneering initiatives with the democratic process that transform some of their major results into laws, or official best practice recommendations.

\section{From acute societal issues to innovation}

With an organization that generates administrative delays, unnecessary expenses, and maladjustments to the challenges of our times, the French dynamics of the sanitary, social and medico-social world features an urgent need for reforms, views changes, and innovations (Bloch \& Hénaut, 2014). Gerontology-geriatrics and psychiatry-psychic health care are two intertwined domains of this world that concentrate lots of these urgent needs.

\section{Gerontology-geriatrics: Nursing homes critical situation and CCNE call}

Nursing homes in France are called "Host establishments for dependent elderly people" (Ehpad, i.e. in French: Établissements d'Hébergement pour Personnes Âgées Dépendantes). In the following, we use the initials Ehpad to refer to such nursing homes. As in other countries, the socalled Ehpads are medical facilities designed to accommodate dependent people $60+$ years, and needing daily care and assistance to carry out the activities of daily living. Briefly, (main source: Ninth edition of CNSA's key figures for assisted autonomy: https://www.cnsa.fr/documentation/ cnsa_18-05_chiffrescles_page_a_page_bd.pdf) 
facts and figures are the following: Number of Ehpads: 7,438 in 2017; French population in Ehpads: $75+$ years, $10 \%$; $90+$ years, one-third; average age upon entering the institution: 85+ years; average number of health problems per person: 7.9; the expenses of healthcare and care dependency is supported by the national social insurance system, even regarding for-profit institutions; frequency rate of accidents at work in Ehpad is double the average number in France; Ehpad types and distribution: Public institutions $50 \%$, Non-Profit Private Institutions 28\%, and private for-profit institutions $22 \%$ (Lacombe, 2019). For a few decades, there is a growing dissatisfaction regarding living conditions and care in Ehpads, both for resident elders and for professional caregivers (Djellal, 2016). By their rigorous and ruthless management for their survival (public sector) or shareholder profits (for-profit sector), the Ehpads have put themselves, in their majority, under the hegemonic domination of the financial system, leading to a growing number of abuses on the most vulnerable residents. Worse still, as acknowledged by French Minister of Solidarities and Health, the greatest number of severe abuses comes from the $22 \%$ for-profit institutions; and this despite huge profits pocketed by certain forprofit institutions' shareholders (almost 9\% net margin generated from accommodation service sales (ie, non-healthcare and care dependency services) (Lacombe, 2019).

For a decade, the situation became so serious as the French National Consultative Ethics Committee for the Life Sciences and Health' (CCNE) ${ }^{1}$, along with several deputies and senators, rung the alarm bell by means of informative reports, peculiarly in 2018: CCNE Opinion $\# 128^{2}$, parliamentary report of Monique Iborra and Caroline Fiat (including 31 proposals towards a new model of Ehpad) ${ }^{3}$, and report of the French Senate Committee on Social Affairs by Senator Bernard Bonne ${ }^{4}$. Especially, the CCNE stresses that "we are facing an ideology advocating individualistic and voluntarist values for active and productive citizens in the name of a sacrosanct economic vision", inducing the impossibility of perceiving the old people as individuals carrying a form of wisdom and hindsight justly related to their age (Opinion \# 128, p.39); "timeconsuming relational care, and yet so necessary, is denied, not taken into account in the somatic care and accompaniment of people" (p.7), "the current logic of health financing does not allow a real policy of prevention of pathologies linked to aging" (p.41), and "as a general rule, the absence of a systemic approach leads to an oblivion of the person as a whole, and of what could be his / her physical, mental and social well-being: his health" (p.36). Hence its claim: "we can and must think differently about aging" (p.10) ${ }^{5}$, along with its calls to awareness: can we go beyond speeches (p.10)? How

can we contribute to a change in attitudes and a change in the way we look at older people? (p.11).

\section{Psychiatry and psychic health care: Homeless- ness critical situation}

Despite an exemplary commitment of psychiatrists and caregivers, psychiatry is today in a state of unprecedented crisis, and not only in France: As shown by many works and testimonials (Adam, Faucherre, Micheletti, \& Pascal, 2017; Archibald, 2018; Blond, 2016), there emerges a feeling of helplessness in the distance between what would be required to properly treat several categories of patients, and what the psychiatric institutions offer, sometimes in reverse of this requirement. In 2017, the Council of Europe vigorously recalled through its Human Rights Commissioner Nils Muiznieks, the great vulnerability of people with psychosocial or intellectual disabilities and their rights (Muiznieks, 2017).

The state of society is undoubtedly one of the main causes. The number of people in precarious and poor situations continues to increase, hence an increasing number of homeless people. Nearly one-third of them have severe mental illnesses. Moreover, psychiatry in general (Blanchette, 2018; Gottzsche, 2017), and the French hospital system in particular, are going through a major crisis that affects health professionals (Bienvault, 2018), and consequently patients (Béguin, 2018; Mcclelland, 2007; Scott, Rogers, Hwang, \& Zhang, 2006). The French 'Union of public exercise psychiatrists' recently claimed that the establishments are "on the verge of explosion" (Garré, 2018). Such a difficult situation is mainly due to an organizational framework considered as particularly deficient (Sol, 2017, p. 177), and according to Ms Cl. Finkelstein, President of the French National Federation of Associations in Psychiatry: "Too many people are in the hospital because we do not know where to put them" (Béguin, 2018). Finally, for Mrs. F. Blain, spokesperson for the French 'Schizophrenia collective', "we must not clog, but think about a new organization of care" (Béguin, 2018).

\section{The French world of laws, action plans, and ethical lighting}

This sub-section provides an outline of the French laws, action plans and national ethical recommendations that govern or regulate healthcare and social action. They are the result of the democratic process of social change, and societal resilience regarding vulnerability issues due to aging or mental health.

French health and social system: On the road to profound and rapid changes

The French health and social system are so complex - with historical cooperative difficulties be- 
tween health and social care sectors, and lots of rapidly evolving specific aspects - as it is difficult to outline it. However and for the sake of understanding, we present here some major elements of this system related to the acute societal issues previously presented.

In order to ensure the greatest possible effectiveness in the implementation of democratic decisions on national solidarity and person autonomy, the French government created in 2004 an Independent-Living Support Fund especially dedicated to solidarity and autonomy in a broad sense, with a common approach to support for the elderly and disabled. Called 'National Solidarity Fund for Independent Living' (Caisse Nationale de Solidarité de I'Autonomie, CNSA) this establishment is both a fund responsible for allocating financial resources and an agency of animation, expertise, and technical support. It manages a budget of more than 26 billion euros (2019) from public funds. Although still insufficient in view of the scale and urgency of the problems mentioned above, the CNSA's efficiency and proactive approaches are peculiarly helpful. CNSA recently published the following two first chapters of its "Prospective approach of the CNSA board" (in French), a multiannual work programme, in line with the reform agenda and the timeliness of policies for autonomy:

- Chapter 1 (2018): For an inclusive society open to all ${ }^{6}$. The chapter concentrates on the quintessential elements of previously mentioned reports.

- Chapter 2 (2019): Home: the domiciliary approach ${ }^{7}$. This second chapter contains benchmarks, principles, guidelines, methodological proposals, and recommendations for a profoundly renewed aging in place objective, and to foster local, regional and national organisation and cooperation. It has been approved by all CNSA's stakeholders and is supported by all Departmental councils of France.

If the CNSA occupies an important place within the French general framework of the social protection system for autonomy, it is only one part of a much larger health and social care system. The latter allows citizens to enjoy one of the best life expectancies (second highest women life expectancy in the world, 2015), and thanks to health insurance, a high level of support for expenses by institutional solidarity (Chevreul \& Brigham, 2018). However, the system is old, fully oriented towards a curative and individual approach to health, and thus not adapted to new needs resulting from the demographic, epidemiological, economic and ecological transitions. This is why its structure and organization are currently undergoing a deep systemic transformation. Many studies and ministerial reports, such as the 'wise men's report' (Cordier et al., 2013), and the 'France: Health sys- tem review' (Chevreul, Brigham, Durand-Zaleski, \& Hernandez-Quevedo, 2015), along with lots of strikes and social movements, have prepared this enduring transformation movement. In this respect, an important 'Law on the adaptation of the society to aging' led by Marisol Touraine, Minister of Social Affairs, Health and Women's Rights, and Laurence Rossignol, Secretary of State for the Family, Childhood, Elderly People and Autonomy, was passed in 2015. Its vote was a valuable first step towards an in-depth transformation of gerontological practices. It was followed in 2016 by the 'Health System Modernization $\mathrm{Act}^{\prime 8}$. This law includes a series of measures such as the creation of 'Territorial health professional communities', a 'territory-health pact' to fight against 'medical deserts', the creation of territorial support platforms for the management of complex cases by health professionals, the project of refounding the shared electronic health record, and the creation of 'Regional Hospital Groups'. Nevertheless, these two recent laws seemed to not sufficiently affect the entire French health and social system. Hence the launching, in 2018, of a vast 'Health system transformation strategy' including a consultation phase and the drafting of a detailed roadmap by Prime Minister Edouard Philippe, and Agnès Buzyn, Minister of Solidarities and Health. This roadmap includes refocusing health facilities on their technical, emergency and expertise missions, along with the structuring of the city as part of a coordinated collective medical and social actions ${ }^{9}$ (Pon \& Coury, 2018). In order to facilitate the precise definition of this vast transformation strategy, the 'High Council for the Future of Health Insurance' drawn up a report meant to constitutes a reference (HCAAM, 2018).

\section{Gerontology and geriatrics}

This vast reform motion has recently been fostered by the CCNE Opinion \#128 (above mentioned). The latter is devoted to profoundly reforming certain gerontological and geriatric practices, social representations of old age, and the various places where old people live. Although this opinion expresses unqualified support to the current laws, it aims to provide them some indispensable critical adding. Indeed, the CCNE considers that things go wrong in the very heart of our society, and thus proposes a package of recommendations, here reduced to the 15 most telling ones (Rialle, 2019): (1) to educate children very early "in their relationship with the elderly and in their early awareness of the concept of solidarity", (2) to "change the verbal standards", and to ban expressions that are too ambiguous or degrading, (3) to encourage the media to broadcast a positive vision of old age, (4) to "rethink the notion of performance in terms of complexity, singularity, and uncertainty", (5) to design new health and social care professions, (6) to 
recognize the place of the caregiver, and to reflect on the establishment of a universal right to respite for caregivers, (7) to rethinking solidarity through an evolution of social legislation in favor of old people in extremely precarious conditions, and to consider new forms of volunteering, (8) to create the role of an interministerial delegate for the protection of adults in order (9) to emphasize the mission of both national education and the media regarding the development of a 'culture of prevention' to better anticipate crititical situations of old or vulnerable people, (10) to fight isolation, exclusion and concentration of older people among themselves, namely thanks to new intergenerational dynamics, (11) to use wisely "the digital revolution, domotics and robotics for solidarity $^{\prime 10}$, (12) to reaffirm the value of neighbourhood professions, and to create new health and social trades, (13) to develop an appropriate adaptation of the housing of the elderly, (14) to promote and diversify alternatives to the Ehpad on the same territory, and finally (15) to design the "Ehpad outside the Ehpad and the Ehpad of tomorrow". Although many of these proposals are already considered in current health and solidarity policies, CCNE intends to vividly foster them in order to both show the rationale that connects them and "go beyond speeches". The CCNE Opinion \#128 had a true repercussion in a recent major citizen survey launched by the government in October 2018 at national, local and citizen levels (Libault, 2019) ${ }^{11}$ (414,000 participants, 18,000 proposals, more than 500 local actors mobilized, and 1.7 million votes).

This wide-ranging reform movement includes also the fostering of the French 'Silver Economy' (SE) action plan that was launched in 2013 by a previous ministerial team, with the remark: "innovation will have to be total" (Ministère-desAffaires-sociales-et-de-la-Santé, 2013, p. 8; "Author", 2016). This SE plan constituted one of the most promising social and economical government efforts regarding ageing and society to such an extent that Mrs. L. Rossignol, who was then 'State Secretary for the Family, the Elderly and Autonomy' claimed in 2016: "Recognized as a sector of the future, [Silver économy] is undeniably the place for a tremendous proliferation of ideas, discussed and exchanged without barriers or compartmentalization"12. However, six years after its launch, the French SE action plan is very slowly developing, and thus its goal of economy revival has not yet been achieved. Besides, in order to prevent the SE from being only a vast marketing operation, as it is also to be feared, the CCNE Opinion \#128 recommends "to give another meaning to the term "silver economy", that is, to go beyond the ideas of 'products' and 'market'"' (p. 10).
Psychiatry and psychic health care

Under the effect of extreme social and medical pressures induced by the critical situation of the psychiatric sector, twelve emergency measures were announced in January 2018 by the minister A. Buzyn. Actually, they complimented an already substantial scheme which peculiarly includes a "Territorial project of mental health" (TPMH) (Decree No. 2017-1200 of 27/07/2017). Indeed, the TPMH organizes "the promotion of mental health, the continuous improvement of people's physical and mental health status, the promotion of people's abilities and their maintenance or commitment to an active social and civic life $\mathrm{e}^{\prime 13}$. It also promotes a fully active psychiatric institution at the heart of society, ineffective interaction with people with mental disorders at both preventive and curative levels. It provides in particular "the organization of a follow-up out of hospitalization, if necessary by a social or medico-social support, to avoid breaks in the course of care", along with "the development of adapted and diversified services designed to facilitate people's access to housing, employment, schooling, studies, and social life, with as much focus as possible on the insertion and retaining in the social area", and "actions to combat the stigmatization of mental disorders and psychic disability" (see the immediately preceding footnote). Moreover, the French psychiatric institution did not wait for this TPMH decree to implement the return of some patients at home, including in many cases a medico-social support and multidisciplinary extra hospital follow-up over several months based on a group of partners (nurse coordinator, social worker, possible family carers ...), an inter-partnership agreement, the possible realization of work of adaptation or repair of housing, etc.; the use of therapeutic adapted apartments in small units in urban areas is also not new. Thus, the French psychiatry sector does not lacke progressive, ambitious and non-conforming initiatives, but only means and a renewed organization for extending their scope, which currently remains very small.

\section{Unifying and internationalizing digital ethics and health ethics}

In a recent CCNE working group report, the latter acknowledges: "Responding to ethical issues associated with digital health dissemination will benefit from an international plan" (CCNE-Digital-Health-working-group, 2018, p. 9). So, the need for international ethical supervision of digital health (Rialle et al, 2014) is taken into account by the highest French ethical authority. Moreover, the project to merge digital health ethics and health and life sciences ethics is in perspective: The CCNE "should evolve towards a National Committee of Ethics whose college would be able to work on ethical issues affecting both the 
life sciences and health as well as the sciences, technologies, use and innovation of digital" (CCNE-Digital-Health-working-group, 2018, p. 8).

\section{Innovation and disruption}

This sub-section is devoted to ways towards a truly innovative society, that is to say in terms of above-presented concepts, ways for thinking differently, going beyond speeches, achieving "total innovation", and "thinking globally and acting locally" (Rialle et al., 2016). It includes the four following parts: (1) A reflection regarding the necessary cultural leap; (2) A presentation of the notion of tekhnè (or technê) as a way to think technology differently; (3) Two complementary implementations: some tools for the art of gerontology, and some other ones for the art of psychic health care.

\section{Cultural leap needed to meet the ongoing challenge} Thanks to the digital world effervescence and its potential to empower a growing part of humanity, our societies indisputably produce places of great creativity, ageing issues being particularly challenging, and technology offering a wealth of tools for creativity boosting. As for the French case, both the above outlined current setting of health and social policy reforms, along with with the wealth of calls for projects in support to social, and entrepreneurial innovation issued by several public and private stakeholders, gives rise to innumerable projects and initiatives ( $\mathrm{Ri}$ alle, 2017a \& 2017b).

However, such technology-oriented creativity meets strong difficulties to go beyond the first steps of little sized experiments, and to achieving the targeted significant innovation uptake. Moreover, besides the growing development of homecare technologies to face growing needs in healthcare and social care provision, the risk to develop a technological society obsessed with profitability and 'modernization', and bringing about a demotion of humaneness is more and more pointed out. Since the development of emerging technology by far outpaces public debate regarding possible malevolent consequences of its use, questioning regarding relevance and negative use has become critical, especially for people living at home or in nursing homes with loss of autonomy. Some steps are still to pass for achieving the true social change at stake, i.e. (a) a large-scale uptake of technologies and ICT-based services useful to frail people in their everyday life, and indispensable for the society to face its various challenges, and (b) the constant and powerful ethical control, by health and social authentic practitioners supported by a clear and up to date human rights-based legislation, and an informed governance. For such an important achievement, there is a need to rethink the definition and role of technology for vulnerable people, care and wellness.

Tekhnè: forgotten sense and missing link towards total innovation

The impetus of such a programme is already resting at the core of the word "technology". Indeed, a glimpse of the content of the word may open new ways for thinking and acting differently. So, what means "technology"? The English etymology dictionary (www.etymonline.com) states: "technology (n.): 1610s, a discourse or treatise on an art or the arts," from Greek tekhnologia "systematic treatment of an art, craft, or technique," originally referring to grammar, from tekhno-, combining form of tekhnè "art, skill, craft in work; method, system, an art, a system or method of making or doing ${ }^{\prime 14}$. Prior to the first computer, the Dictionary of the French Academy defined it, in its $8^{\text {th }}$ edition (1932-1935), as "science, treatise on the arts in general"15. Basically, technology is the study (logia) of tekhnè, this greek term including the triad of science, art, and skill (SAS). The current meaning of technology as high-tech objects to be embedded in machines to allow for mechanical operation is both very recent and restrictive, albeit the widely used. Now, this restrictive meaning has clearly lost the richness of the humane connotation provided by the SAS triad, which still does define the word technology.

However, it so happens that the same SAS triad may also characterize most of the specific activities and professions related to care and assistance to the elderly or any people with loss of autonomy, as attested namely by the recent WHO Guidelines on Integrated Care for Older People $^{16}$. All these activities require "method of doing" (cf. above), thus tekhnè, thus technology in its plain etymological sense.

It happens also that the current very narrow and biased sense of technology induces a certain distance, sometimes divorce, between designers and users: "Despite the rhetoric and hope for digital health, however, patients are not using the tools as much as they could. Typical medical or fitness apps have a 90-day user retention rate of only $27 \%$ to $30 \%, 10$ and $50 \%$ of these apps are downloaded less than 500 times. The low usage of current digital health tools is not, interestingly, due to a lack of demand." (Birnbaum, Lewis, Rosen, \& Ranney, 2015).

Therefore, the rich and open meaning content of tekhnè above presented could both meet the vastness of the change required by CCNE (cf. supra, 15 recommendations), and significantly reduce the gap between the current digital and robotic world and the world of health and social care. 
As the tekhnè mobilized by care professionals or volunteers involves the design and use of certain technological tools, it would stimulate a 'demanddriven' for digital tools and assistive technologies by professionals or volunteers, and so reduce the above-mentioned distance. The specter of the enduring 'technology push' that dominates the digital and robotic world, would thus decrease. Thanks to its plain meaning, the word 'technology' might endorse a new economic and social efficiency. Need-based, demand-driven design and uptake of technological tools would fully participate in the 'total innovation' above mentioned. Reconsidered as tekhnè, 'technology' would no longer be the preserve of engineers or scientists, and might be easily endorsed by professionals or family caregivers, as well as lots of health and social care stakeholders.

\section{Tools for the art of gerontology and geriatric medicine}

Regarding the gerontology-geriatric sector concerned by technology for people with cognitive disabilities (Kenigsberg et al., 2017; Tisseron, 2018), and especially maltreatments or degradation of quality of life in certain settings, we are witnessing the emergence of new abilities to tackle the issues of motivation loss, hopelessness, apathy, wandering, suicide,... of old people living alone or in nursing homes with a lack of qualified staff. Here are three examples, that also relate to psychic health care.

First, the Ph.D. works of Lisa Quillion-Dupré, a clinical psychologist: The goal of her recent research is twofold: (a) to determine whether old people encountered specific difficulties in using new information and communication technology, in order to offer them an adapted support, (b) to provide professional or family caregivers with a series of recommendations about how to teach the use of these technologies to people with moderate to severe cognitive disorders (Quillion Dupré, 2018). Her research results show that older adults are characterized, first, by a greater number of errors of commission than other ones (i.e. errors of initiation, addition, or omission), and second, by a need for more precise and explicit cues than younger people would require, especially for the use of mobile technology. She also established that using both the "errorless learning" technique and the "spaced-retrieval" techniques to teach how to use touch screen tablets provides valuable results among people with severe neurocognitive disorders. She provides examples that dispel stereotypes that cognitively disabled old people cannot be reached to use these tablets. Thus, she allows professional caregivers such as nurses or geriatric social workers to acquire new skills while bringing back elders' missing smiles. Such dazzling results permitted

her to be laureate of the "2018 Thesis Award" of the French Foundation Médéric Alzheimer ${ }^{17}$.

Second, the design and realization, by Christine Roosen, former hospital clinical psychologist, and a team of designers, of Interactive stations called TIPATSMA tables (Duchossoy, Roosen, Maranzana, Trivalle, \& Buisine, 2015). These stations are the result of several years of observation, as a clinical psychologist, of patients with severe neurocognitive disorders hosted in specialized hospital units. She especially observed patients' situations, such as wandering, that generate aggression on the part of patients, and that causes stress, helplessness, and dissatisfaction among caregivers. Moreover, the latter was, of course, aware of the deleterious effects of some drugs used as a last resort. These TIPATSMA stations are scientifically and aesthetically designed. Christine Roosen pinpoints that "the TIPATSMA table consists of noble materials, objects, and systems to attract the eye, invite manipulation and observation, and stimulate the senses. It has been meant to be non-stigmatizing: Halfway between the abstract work of art and the handyman's workbench, it is at hand on the walls of the wandering path. Unbreakable, it is nevertheless equipped with detachable elements that patients can freely and safely handle and carry with them". She adds: "The origin of wandering is multifactorial. It is very important to eliminate reasons that signify an acute affection or anxiousness with anguish. Once analyzed the various somato-psychic factors that can explain a wandering or sudden agitation that can be remedied, it is important to let this wandering, this motor activity to be done and, of course, safely. To appropriate the space, to give oneself moments of freedom by leaving the collective spaces, far from the others' eyes, seems to allow the patients to find their rhythm, to regain certain confidence in them. Can those who can no longer walk and who take refuge - often by closing their eyes - in a certain apathy, seek in themselves this reassuring dialogue with themselves?"

Third, research about communication links that humans may shape with robots by means of speech and prosody conducted by Véronique Aubergé $^{18}$ and her team (University Grenoble Alpes) (Aubergé et al., 2014; Cailloce, 2017). According to V. Aubergé, emotions, which are the result of involuntary control, are inseparable from cognitive decisions. She points that, given these social emotions are at the very root of language interaction between human beings, not giving this social-emotional capability of words to robots makes them run the risk of being perceived as autistic. However, conversely, endowing them with realistic socio-affective performances, without utterly mastering the process 
and the functionality of their skills may have adverse psychological results. Especially, an automaton designed with the sole purpose of keeping him or her company "is extremely dangerous as long as we do not know exactly what is at play in the interaction with humans" (Cailloce, 2017). Aubergé explains that "what separates the social robot from a connected smart object is not so much the complexity of the artificial skills that are given to it as characteristics that make it perceive as an "other" increasing our human social space. We are faced with an empathic illusion." Hence the importance of using nonhumanoid robots. Her research results "show how such non-humanoid service robots can dynamically build a supposedly "altruistic" relationship (without dominance) by some basic communication modalities. By studying the modes of exchange observed between socially isolated older people and the robot, new forms of a socio-emotional bond are emerging. The robotic tool thus makes it possible to reinforce the social bonds of elderly people in a situation of isolation and fragility". As she does, her research topic invites researchers to investigate the human psychological core. Such research induces in researchers or people interested in the topic, a questioning hitherto restricted to circles of therapists or philosophers, with questions such as: what is a true aiding relationship? What is mental health? What is a "good life" especially for people facing strong psychological difficulties? Etc.

The idea of robotics devoted to a genuine helping relationship (Rialle, 2018a; Tisseron, 2018) rests on concepts and reflections amenable to humanitarian robotics (HR), an expression coined to mean a way to efficiently help vulnerable people facing very difficult situations, and, in the other hand, in opposition to robotics for war (including business war), which is one of the main research and development efforts for cutting edge robotics. Regarding the French case under study, the concept of humanitarian robotics is likely to meet several CCNE recommendations, especially its inducement $(k)$ to purposely use "robotics for solidarity" (cf. supra).

\section{Tools for the art of psychiatry and psychic health} care

Research and reflection about Assistive technology to cope with cognitive disorders such as schizophrenia or socio-emotional disabilities, and to favor psychic health care have increased in recent years (Bier et al., 2018; Briand et al., 2018; Harvey \& Se Keefe, 2012; Sablier, Rialle, \& Robert, 2012; Stip et al., 2013; Tisseron \& Tordo, 2018). The French Auvergne-Rhône-Alpes Region entered this area in the early 1990's in cooperation with Canada (Rialle \& Stip, 1994; Stip $\&$ Rialle, 2005). Thanks to the international fran- cophone project DARAMS ${ }^{19}$ (Innovative devices for assistance and autonomy of people with cognitive disability), the cooperation with Canada was still living in the 2010's (with Switzerland, lately included): This project has highlighted the important potential of digital tools for psychiatry and gerontology (Bier et al., 2018). The DARAMS team has also vividly contributed, since 2016, to the renewal of the ISG Francophone Chapter.

As for the art of psychiatry and psychic health care, let us briefly outline some research results regarding schizophrenia and mental disorders frequently related to homelessness, i.e. the psychiatric social issue previously detailed. In this sector, mobile applications (apps) providing digital psychic personal assistance have been available for a few years on smartphones and tablets. As an illustration, Table 1 shows a shortlist of mobile apps recently used in Quebec (Canada) by Catherine Briand et al. (Briand et al., 2018) with 11 patients suffering from schizophrenia, schizoaffective disorders, mood disorders, personality disorders, accompanied by cognitive or socio-emotional disabilities.

The latter study also showed that personalized human assistance was essential for the use of these apps by patients. In addition, it is useful in psychiatric clinical practice to know the importance of cooking activities. In this respect, some technological innovations validated in psychiatry have been used for homecare (Stip et al., 2007). It should also be noted that the recall of safe medication taken by the use of electronic pillboxes at home has been validated in psychiatry by a rigorous study in 2013 (Stip et al., 2013). Thus, the development and implementation of a program of innovative practices to support a patient in non-hospital settings can now be done in a few days by a team trained to put these innovations in practice. Now, a question is: are such innovative psychiatric practices legal and clearly supported by laws? The answer regarding the French case is clearly positive. As previously pointed, laws in France are quite ready for nursing practice innovation and their ethical supervision. For instance, the 'General Nomenclature of Professional Acts' (NGAP) provides the basic framework for innovations in nursing practice: It provides for "Nursing home care for a patient, regardless of age, in a situation of temporary or permanent dependence", including "the implementation of a personalized assistance program to promote its maintenance, insertion or reintegration into the framework of family and social life" ${ }^{\prime \prime 20}$. As long as they are well used, that is, inserted into training curricula and controlled end-to-end to serve psychiatric patients and health and social support professionals, these digital tools can provide powerful levers for opening ways and thinking about a new organization of care. 
Table 1. List of apps proposed to participants with psychiatric disorders in a study by Briand et al. (2018)

\section{Exemples of apps}

Calendar; Notes; Clock; Wunderlist

STM-subway; Google Maps

Mail; Facebook

Youtube; Scrabble; Culture Access

LPmobile

ShopShop-Shopping list

Dictaphone; Offline dictionary

Desjardins

Pedometer GPS; Nike Training; Glucose Companion

Alarm; RxmindMe Prescription

Respiroguide; Optimism; Relax M.O.; Way of life

Music

Sudoku; Cut the rope

Bible.is

\section{ShORT Discussion AND CONCLUSION}

The reason of the paper was to explore the interest to carry out a reflective study about the societal resilience being operated to meet challenges in ageing and social difficulties of a psychic health nature; in other words, to contribute to the perspective of a sustainable humanity for each country or region of the world, using the French case as a real textbook case. Although still little developed among researchers in gerontechnology, this perspective is fully reflected in the objectives of the ISG: "In classical economics of ageing nations, the societal burden of care for seniors appears unsustainable. The solution could lay in a strong emergence of new cooperative economic paradigms of solidarity convergence of networks, cooperative mode, participatory finance, participatory creation, and a functional economy" (Franco \& van Bronswijk, 2016). Hence the wide scope of themes and author's paper described in the method section.

The interest to carry out such a reflective study could only be aroused by going so far as to propose some methodological hints accompanied by specific examples. So, no matter what country or region under study, the proposed successive steps to both explore and foster the resilence understudy may be summarized as follows:

(1) Describe problems as they are experienced and expressed by individuals, professionals, politicians, etc. (Awareness maturation step).

(2) Describe what is done or planned at the public policy level: legislation, orders in council, transformation programs or transition, ethical opinions (Public policy step).

\section{Apps' objectives}

To organise my time and manage my tasks

To help me get around and use transit

To keep in touch with my friends and/or family

For entertainment and to pass the time

To keep up-to-date on the news

To shop

To facilitate my professional and academic activities

To manage my budget

To improve my physical health

To manage my medication

To handle my anxiety and moods

To better cope with my voices

To stimulate my cognitive functions

To grow at a spiritual and religious level

(3) Describe pioneering initiatives and achievements to change ways of doing things, think differently, and prepare for a new society (Social Innovation and positive disruptive thinking step).

Actually, the proposed approach pertains to the action-research category (Hart \& Bond, 1995), a kind of research that simultaneously fosters social change and serves science. To do such a resilience study, the national level is not mandatory; the approach may judiciously apply at any local or regional level in a given country. It is sufficient to describe what is happening at the chosen level, even if the laws used at that level are passed and applied at a wider level (e.g. national level in the current French situation and partially European level). Successfully achieving such a goal presupposes to adopt a scientific attitude relying on possibly existing trusted documents to support any interpretation.

Recourse to the original meaning of the word technology makes it possible to greatly enrich the field of gerontechnology, which often remains centred on the narrow sense of this word. Such a recourse might allow not only to escape the 'technology push' rationale, but also to include many professionals, stakeholders, and people from very different cultures.

The proposed approach serves also to extend the scope of gerontechnology towards both reflective research and resilience. It targets the levels of regions or countries. It also provides some hints to answer the question: How to put humanity back at the heart of the economic and social 
system while developing gerontechnological efficiency? Thus, it bolsters the way "to achieve a better quality of life and active healthy aging" proposed by ISG as the major perspective of its international dedication.

\section{Endnotes}

${ }^{1}$ https://www.ccne-ethique.fr/en/pages/presenting-national-consultative-ethics-committee-health-and-lifesciences (consulted on 2019/01/13)

${ }^{2}$ Report title: "Avis n 128 (15 février 2018) Enjeux éthiques du vieillissement »: https://www.ccne-ethique. $\mathrm{fr} /$ sites/default/files/ccne_avis_128.pdf, (consulted on 2018/12/28)

${ }^{3} \mathrm{http}: / /$ www.assemblee-nationale.fr/15/rap-info/i0769. asp (consulted on 2019/01/09)

${ }^{4}$ https://www.ladocumentationfrancaise.fr/rapportspublics/184000144-rapport-d-information-fait-aunom-de-la-commission-des-affaires-sociales-sur-la-situation (consulted on 2019/01/09)

${ }^{5}$ Quotations of this paragraph are personnal translations of sentence fragments from the Opinion \# 128 (cf. end note \#2), and are followed by the page number of the fragment.

6"Démarche prospective du conseil de la CNSA - Juillet 2018. Chapitre 1: Pour une société inclusive, ouverte à tous": https://www.cnsa.fr/documentation/web_ cnsa_13-08_dossier_prospective_exe1.pdf

7 "Démarche prospective du conseil de la CNSA - Juillet 2019. Chapitre 2 : Chez-soi : I'approche domiciliaire": https://www.cnsa.fr/sites/default/files/cnsa_-_chapitre_ prospectif_2019.docx

8French: "Loi de modernisation du système de Santé"

${ }^{9} \mathrm{https}$ //www.strategie.gouv.fr/sites/strategie.gouv.fr/ files/atoms/files/avis_et_rapport_hcaam_2018_-_ contribution_a_la_strategie_de_transformati.pdf (consulted on 2018/12/12)

${ }^{10}$ Here again, the quotes of the whole paragraph and the following one are personnal translations of sentence fragments from the French CCNE Opinion \# 128 (cf. end note \#5).

${ }^{11}$ D. Libault's ministerial report: https://www.vie-publique.fr/sites/default/files/rapport/pdf/194000302.pdf

${ }^{12}$ Personnal translation from the French. Cf. http://www. silvereco.fr/annuaire-officiel-de-la-silver-economieedito-de-laurence-rossignol/3132996 (consulted on 2018/12/12)

${ }^{13}$ https://www.legifrance.gouv.fr/eli/decret/2017/7/27/ SSAH1710848D/jo (consulted on 2019/01/08)

${ }^{14}$ https://www.etymonline.com/search?q=technology (consulted on 2019/01/08)

${ }^{15} \mathrm{Cf}$. http://artflx.uchicago.edu/cgi-bin/dicos/pubdico1look. pl?strippedhw=technologie (consulted on 2019/01/08)

${ }^{16} \mathrm{Cf}$. https://www.who.int/ageing/WHO-ALC-ICOPE_ brochure.pdf?ua=1 (consulted on 2019/07/20)

${ }^{17} \mathrm{Cf}$. https://www.fondation-mederic-alzheimer.org/alzheimer-quels-acteurs-font-bouger-les-lignes-en-2018 (consulted on 2019/01/07)

${ }^{18} \mathrm{Her}$ research involves integrating cognitive and social functions into robotic systems to create interactive social robots. Cf. https://www.liglab.fr/fr/evenements/keynote-speeches/veronique-auberge-affecte-affectueuxaffectif-quand-I-affective (consulted on 2019/01/05)

19"Dispositifs d'Assistance, de Réadaptation et d'Autonomie pour Malades atteints de troubles cognitifs Modérés à Sévères". Final report: http://www. rialle.eu/darams/rapportfinaldarams.pdf (consulted on 2919/01/11)
${ }^{20}$ NGAP, version 14/04/18, Title XVI - Nursing, Chapter I - Routine Care, Section 11, 104. Cf. https://www.ameli. $\mathrm{fr} /$ medecin/exercice-liberal/remuneration/nomenclatures-codage/ngap (consulted on 2019/01/05, personnal translation)

\section{References}

Adam, C., Faucherre, V., Micheletti, P., \& Pascal, G. (2017). La santé des populations vulnérables. Paris: Ellipses.

Archibald, S. (2018). Je ne fais pas une vraie dépression et je suis un fraudeur. La Press+ (édition du 11 février 2018), http://plus.lapresse.ca/screens/ffe $9 \mathrm{fb} 3 \mathrm{~b}-\mathrm{f} 2 \mathrm{fb}$ 4329-bda8-df82f94ec613_7C___.html.

Aubergé, V., Yuko Sasa, Y., Bonnefond, N., Meillon, B., Robert, T., Rey-gorrez, J., Nebout, F. (2014). The EEE corpus: socio-affective "glue" cues in elderlyrobot interactions in a Smart Home with the EmOz platform. Paper presented at the 5th International Workshop on Emotion, Social Signals, Sentiment \& Linked Open Data, Reykjavik, Iceland. http:// hal.univ-grenoble-alpes.fr/docs/01/00/39/10/PDF/ ES3LOD_Auberge_al.pdf

Béguin, F. (2018). La psychiatrie en grande souffrance. le Monde, daté du 25/01/2018.

Bienvault, P. (2018). Quand I'hôpital devient un «lieu de maltraitance » pour ses soignants. La Croix, 9 janvier.

Birnbaum, F., Lewis, D., Rosen, R. K., \& Ranney, M. L. (2015). Patient engagement and the design of digital health. Acad Emerg Med, 22(6), 754-756. https://doi.org/10.1111/acem.12692

Blanchette, J. (2018). Déprimer en souriant. Le Devoir, (du 16/02/18: https://www.ledevoir.com/opinion/ chroniques/520386/deprimer-en-souriant).

Bloch, M. A., \& Hénaut, L. (2014). Coordination et parcours - La dynamique du monde sanitaire, social et médico-social Paris: Dunod.

Blond, M. (2016). Étude sur les difficultés actuelles du métier de psychiatre hospitalier français De la flamme au burn out. L'information psychiatrique, 92(8), 625 - 639. https://doi.org/10.1684/ ipe.2016.1531

Briand, C., Sablier, J., Therrien, J. A., Charbonneau, K., Pelletier, J. F., \& Weiss-Lambrou, R. (2018). Use of a mobile device in mental health rehabilitation: $A$ clinical and comprehensive analysis of 11 cases. Neuropsychol Rehabil, 28(5), 832-863. https://doi. org/10.1080/09602011.2015.1106954

Cailloce, L. (2017). The Challenges of Social Robotics (interview of Véronique Aubergé). CNRS - Le Journal (Blog: https://news.cnrs.fr/articles/the-challenges-of-social-robotics).

CCNE-Digital-Health-working-group. (2018). Numérique \& santé : Quels enjeux éthiques pour quelles régulations? . Paris: CCNE.

Chevreul, K., \& Brigham, K. B. (2018). Health System in France Health Care Systems and Policies [Internet] (pp. 1-10): Springer US. https://doi.org/10.1007/978- 
1-4614-6419-8_9-1

Chevreul, K., Brigham, K. B., Durand-Zaleski, I., \& Hernandez-Quevedo, C. (2015). France: Health System Review. Health Syst Transit, 17(3), 1-218, xvii.

Cordier, A., Chêne, G., Duhamel, G., de Haas, P., Hirsch, E., Parisot-Lavillonnière, F., \& Perrotin, D. (2013). Un projet global pour la stratégie nationale de santé. 19 Recommandations du comité des «sages». Rapport pour le Ministère des Affaires sociales, de la Santé et des Droits de la femme et pour le Ministère de l'Enseignement supérieur et de la recherche. Juin.

Dewey, J. (1998). How we think: a restatement of the relation of reflective thinking to the educative process. Boston: Houghton Mifflin.

Djellal, A. (2016). Le burn-out des soignants vu par un directeur d'Ehpad. L'Aide-Soignante, 177. https:// doi.org/10.1016/j.aidsoi.2016.03.007

Duchossoy, M., Roosen, C., Maranzana, N., Trivalle, C., \& Buisine, S. (2015). Conception de tableaux interactifs pourpatients atteints de troubles sévères de lamaladie d'Alzheimer (Tipatsma). NPG Neurologie - Psychiatrie - Gériatrie. https://doi. org/10.1016/j.npg.2015.02.004

Franco, A. A., \& van Bronswijk, J. E. M. H. (2016). Gerontechnology: Push research and pull innovation for a sustainable humanity. Gerontechnology, 15(0), 1-2. https://doi.org/10.4017/gt.2016.15.s.002.00

Garré, C. (2018). Plan psychiatrie : la profession salue... mais attend des mesures concrètes et des financements supplémentaires. Le Quotidien du Médecin, 31/01/18.

Gottzsche, P. C. (2017). Psychiatrie mortelle et déni organisé. Québec, Canada: Presses de I'Université Laval (Traduction: F. Turcotte).

Hart, E., \& Bond, M. (1995). Action Research for Health and Social Care. London: Open University Press.

Harvey, P. D., \& Se Keefe, R. (2012). Technology, society, and mental illness: challenges and opportunities for assessment and treatment. Innov Clin Neurosci, 9(11-12), 47-50.

HCAAM. (2018). Contribution à la stratégie de transformation de notre système de santé. Paris: HCAAM (https://www.strategie.gouv.fr/publications/contribution-transformation-systeme-de-sante).

Keck, M., \& Sakdapolrak, P. (2013). What is social resilience? Lessons learned and ways forward. ERDKUNDE - Archive for Scientific Geography, 67(1), 5-19. https://doi.org/10.3112/erdkunde.2013.01.02

Kenigsberg, P. A., Aquino, J. P., Berard, A., Bremond, F., Charras, K., Dening, T., Manera, V. (2017). Assistive technologies to address capabilities of people with dementia: From research to practice. Dementia (London), 1471301217714093. https://doi. org/10.1177/1471301217714093

Lacombe, C. (2019). Le business de la dépendance. L'Obs, 2853, 18-24.

Libault, D. (2019). Concertation Grand Âge et Autonomie - Grand Âge, le temps d'agir. Retrieved from Paris: https://www.ladocumentationfrancaise.fr/ rapports-publics/194000302-concertation-grandage-et-autonomie

Mcclelland, L. (2007). Examining the Effects of Fatigue on Decision- Making in Nursing: A Policy-Captur- ing Approach (Vol. 154): All Dissertations (Industrial and Organizational Psychology Commons).

Ministère-des-Affaires-sociales-et-de-la-Santé. (2013). Contrat de filière Silver économie: Ministère des Affaires sociales et de la Santé (http://www.socialsante.gouv.fr/IMG/pdf/Contrat_Silver_economieMEP-9-12-2013-v6.pdf).

Moallem, M. (1998). Reflection as a Means of Developing Expertise in Problem Solving, Decision Making, and Complex Thinking of Designers. Paper presented at the 1996 National Convention of the Association for Educational Communications and Technology, Indianapolis, US. https://www.academia.edu/attachments/51450368/download_file? st=MTU0ODc0ODAyOSwxNzYuMTkxLjEwLjI1LD EwMTAxNDg1Ng\%3D\%3D\&s=work_strip

Morin, E. (2008). On Complexity. Cresskill, NJ, USA: Hampton Press.

Muiznieks, N. (2017). Respecter les droits de I'homme des personnes ayant des déficiences psychosociales ou intellectuelles : une obligation qui n'est pas encore pleinement comprise. Le Carnet des droits de l'homme, Conseil de l'Europe.

Pon, D., \& Coury, A. (2018). Stratégie de transformation du système de santé - Rapport final : Accélérer le virage numérique. Retrieved from Paris: https:// www.ladocumentationfrancaise.fr/var/storage/rapports-publics/184000613.pdf

Quillion Dupré, L. (2018). Use of the touch pad by the elderly. An ecological approach to evaluation and learning assistance. (PhD thesis), University Grenoble Alpes, Grenoble, France.

Rialle, V. (2016). Technologie et innovation totale : pour une re-naissance de la tekhnè dans la Silver économie. Revue de Politique et Parlementaire, 1081, 69-77.

Rialle, V. (2017a). Vie collaborative - modes émergents. In J. P. Aquino (Ed.), L'Officiel des Aînés (Vol. 3, pp. 113-120). Paris: Ministères de l'Etat français.

Rialle, V. (2017b). Villes intelligentes sources d'inspiration. In J. P. Aquino (Ed.), L'Officiel des Aînés - 3e édition (pp. 107-112). Paris: Ministères de l'Etat Français.

Rialle, V. (2018a). [Humanitarian robotics versus suicidal robotics: how to re-enchant the Silver economy?]. Journal de Médecine Légale - série Droit, Santé, Société, 61(4), 17-25.

Rialle, V. (2018b). Technologies et santé des personnes âgées. In J. Belmin, P. Chassagne, \& P. Friocourt (Eds.), Gériatrie pour le praticien (3e édition) (pp. 944-946). Paris: Elsevier Masson.

Rialle, V. (2019). Avis n 128 du Comité consultatif national d'éthique pour les sciences de la vie et de la santé (CCNE) sur les «Enjeux éthiques du vieillissement»: Présentation et commentaires. Journal de Médecine Légale - série Droit, Santé et Société, 62(1),28-30.

Rialle, V., Forest, F., Verdier, C., Rieu, D., Front, A., Mercier, A., et al. (2016). How to think globally and act locally for health path, and elders' autonomy with eHealth and Gerontechnology? Gerontechnology, 15(0), 159s.

Rialle, V., Rumeau, P., Ollivet, C., Sablier, J., \& Hervé, C. (2014). Télémédecine et gérontechnologie pour la maladie d'Alzheimer : nécessité d'un pilotage 
international par l'éthique. Journal International de Bioéthique, 25(3), 127-145. https://doi.org/10.3917/ jib.253.0127

Rialle, V., \& Stip, E. (1994). [Cognitive modeling in psychiatry: from symbolic models to parallel and distributed models]. Journal of psychiatry \& neuroscience : JPN, 19(3), 178-192.

Sablier, J., Rialle, V., \& Robert, B. (2012). Tracking or talking? What do people with Alzheimer disease and their caregivers expect from assistive technologies? Example of a GPS-based tracking system. Paper presented at the 22nd Alzheimer Europe Conference "Changing perceptions, practice and policy", 4-6 October 2012, Vienna.

Sol, H., \& Rialle, V. (2018). [Rethinking the Organization of Psychiatric Care in the Age of the Internet of Things]. Journal de Médecine Légale - série Droit, Santé, Société, 61(5-6), 45-58.

Stip, E., \& Rialle, V. (2005). Environmental cognitive remediation in schizophrenia: ethical implications of "smart home" technology. Canadian journal of psychiatry. Revue canadienne de psychiatrie, 50(5), 281-291. https:// doi.org/10.1177/070674370505000509

Scott, L. D., Rogers, A. E., Hwang, W. T., \& Zhang, Y. (2006). Effects of critical care nurses' work hours on vigilance and patients' safety. Am J Crit Care,
15(1), 30-37.

Sol, H. (2017). Les IOT au service du "chez soi d'abord" : comment favoriser l'autonomie, à domicile, des patients atteints de pathologies psychiatriques, par l'achat hospitalier d'outils technologiques innovants? (Master dissertation). Institut d'Administration des Entreprises, Grenoble, France.

Stip, E., Sablier, J., Sephery, A. A., Rivard, S., Cloutier, C., Aubin, G., Limoges, F. (2007). Cuisine et schizophrénie : activité carrefour d'une évaluation écologique, ergothérapique et neuropsychologique. Santé Mentale au Québec, 32(1), 159179. https://doi.org/10.7202/016514ar

Stip, E., Vincent, P. D., Sablier, J., Guevremont, C., Zhornitsky, S., \& Tranulis, C. (2013). A randomized controlled trial with a Canadian electronic pill dispenser used to measure and improve medication adherence in patients with schizophrenia. Front Pharmacol, 4, 100. https://doi.org/10.3389/ fphar.2013.00100

Tisseron, S. (2018). Petit traité de cyber-psychologie Pour ne pas prendre les robots pour des messies et I'IA pour une lanterne. Paris: Le Pommier.

Tisseron, S., \& Tordo, F. (Eds.). (2018). Robots, de nouveaux partenaires de soins psychiques. Paris: Eres. https://doi.org/10.3917/eres.tisse.2018.02 